Vol. 5, No. 06; 2020

ISSN: $2456-8643$

\title{
POTENTIAL OF GROUNDWATER HARVESTING FOR MICRO IRRIGATION AND ITS WELFARE EFFECT TO HOUSEHOLDS IN KAMARINY, ELGEYO MARAKWET COUNTY, KENYA
}

\author{
Andrew Kiptum and Catherine Chebet \\ School of Environmental Studies, University of Eldoret, P.O BOX 1125-30100, Eldoret, Kenya
}

https://doi.org/10.35410/IJAEB.2020.5585

\begin{abstract}
High underground water levels in household wells during rainy season create a chance to be harvested for micro irrigation by households during dry spell. However, an opportunity to harvest groundwater from household wells has remained untapped. This study explores the potential of harvesting groundwater at household wells for micro irrigation and its possible welfare effect to households. Primary data was obtained using structured questionnaires, where systematic simple random sampling technique was used in this study. Excel and Statistical Package for Social Sciences (SPSS) were used in analysing data. The potential capacity of groundwater that could be harvested by each household and possibly used in micro irrigation is about 25 cubic metres during the wet seasons of May to September. The results on welfare effect on household if groundwater is harvested and used in micro irrigation could improve household's income stream at 1.009 percentage point increase. Socio economic determinants such as household size, number of animals reared and size of kitchen garden was found to significantly influence household water demands at $(\mathrm{t}=1.92, \mathrm{p}<0.1),(\mathrm{t}=1.2 .7, \mathrm{p}<0.1)$ and $(\mathrm{t}$ $=3.75, \mathrm{p}<0.1)$ respectively. However, the random factor value in the regression model showed significant difference at $(\mathrm{t}=1.67, \mathrm{p}<0.1)$ in influencing consumptive demands of groundwater, which explains the need to research more on other factors that influence consumptive demand on water that were beyond the scope of this study. Therefore, these findings will inform policy and decision makers on the strategies of utilising untapped groundwater supply for poverty alleviation and improved food supply to the population.
\end{abstract}

Keywords: Water demands, Socio economics, Income, Welfare effect, Consumptive demands.

\section{INTRODUCTION}

Well-functioning terrestrial ecosystems provides reliable and relatively predictable environmental services such as clean underground water flow, soil amelioration, carbon sequestration and many others which are essential for human well-being. As a result, societies would rely on free provisions of ecosystem service as raw material inputs for industries processes, agricultural production and climate stability (Kemper, 2004; Wada et al., 2010 and Rideout et al., 2013). However, landscape ecosystem faces huge pressure from human activities resulting into degradation and depletion of already scarce resource (Kiptum et al., 2012) 
Of concern is pollution and forest cover reduction which is attributed to human actions where it raises entropy level resulting to global warming and subsequent hydrological cycle disruption (Chen et al., 2010 and World Bank, 2011). When human activities degrade environment i.e. forest cover reduction due to overconsumption through illegal logging, the earth loses its thermostats where extreme weather events would ensue because the functionality of tree cover to sequester heat-trapping gases is lowered (Fei et al., 2009 and Cao et al., 2013).

Inadvertently, burning of organic matter for industrial processes and other human activities leads to increase in carbon dioxide gas productions which concentrate in the atmosphere that could have a positive impact on the growth of plants (Konikov and Kendy, 2005). Despite positive effect of carbon dioxide gas to plants, however, there have been shifts in climatic characteristics from normal to extremities resulting to global warming i.e. high precipitation to prolonged drought, (Wada et al., 2010). The consequence of increased temperatures has led to recession of groundwater volume signalling negative externality from deleterious anthropogenic activities such as reduction in food production in the farms (Cao et al., 2013).

Therefore, effects of climate change reduce the degree of predictability on resource production, thus dependability on resources and element of uncertainty increases which puts human life at precarious position on food production and consumptive processes of natural resources such as water for irrigation and industries (Kemper, 2004; Wada et al., 2010 and Kelemen et al., 2016). For instance farmers who have hitherto depended on indigenous knowledge in predicting weather patterns could falter in food production if for instance dry season prolonged beyond expected period (Kelemen et al., 2016). These could result into social and environmental episodes such as food scarcity, shift in nutrition value, inflationary effect from food scarcity and scarcity of consumable water and/or irrigation and for industrial purposes which negatively affect consumer's welfare (Pastakia, 2011).

Based on aforementioned climatic variability, therefore, there is need to maximise resource when they are at abundances such as water by harvesting from household wells; for instances during high rainfall period to be used in micro irrigation. Use of stored water in artificial reservoirs for micro irrigation could stabilize scarcity of food supply arising from erratic climatic conditions such as long dry spell. Scarcity of water especially during unexpected long dry spelt period could influence low supply of crop production which constrains household income (Nepal et al., 2011). Hence, adaptive strategy in this study, involves maximisation of groundwater during high precipitation that allows high percolation of runoff water into underground by harvesting in household wells. Therefore, the adopted underground water harvesting strategy by household during wet seasons could stabilize idiosyncratic and covariate climatic shocks in food production through micro irrigation during dry periods.

Study by Mogaji et al. (2011) found water recharge into unlined wells during rainy seasons is high than during dry period. Groundwater as described by Brassington (2007) is that part of precipitation that percolates through the earth to the water table to form underground water supply. This saturated water on the earth which percolates through the soil spaces accumulates in modified reservoirs such as boreholes and wells. Water volume in unlined wells tends to increase during rainy season which can necessitate harvesting of such underground water if strategies of harvesting is adopted and stored in constructed tank(s) for future use by households (Mogaji et al., 2011). Thus, underground water harvesting is a driver and enabler for factors of production 
such as food production on land which improves and sustains household welfare by maximizing underground water during rainy season.

To conceptualising maximisation effects of underground water resources in this study for rational and sustainable household utilisation, it can be expressed in a functional form as;

$$
Q=\left(Q_{i}\right) ; i=D_{w}, I_{w}
$$

Where; $\mathrm{Q}$ is the vector of underground water harvesting and for storage for various future uses, while $D_{w}$ and $I_{w}$ represent domestic and irrigation water use, respectively.

The general constraints in maximizing underground water in unlined household wells may be formulated as;

$$
\max _{z \in \Omega(z)} f(z)
$$

Where the objective function $f$ is assumed to be a maximisation function on convectional natural resources, $\mathrm{z}(\mathrm{u}, \mathrm{Q})$ which consists of a vector $\mathrm{u}$ on the nature of the variables and a vector $\mathrm{Q}$ of decision variable, $\Omega_{z}=\Omega_{u} \cup \Omega_{Q}$ is the feasible characteristics of $\mathbf{z}$ which is represented by a set of constraints equations, $\Omega_{u}$ represents the feasible characteristics of $\mathrm{u}$, and $\Omega_{Q}$ represents the feasible characteristics of Q i.e. income stream in form of currency.

Using Booker and Young (1994) maximisation framework in solving water harvesting strategies conditioned by water scarcity with the aimed of improving overall welfare to consumers. Natural resources maximisation framework under scarce condition can be expressed in a functional equation as;

$$
\max _{z \in \Omega(z)} W B_{i}=\sum_{i} W B_{i}\left(Q_{i}, u\right)
$$

Where; $W B_{i}$ are the welfare benefits of incomes that are associated with harvested underground water for maximization through micro irrigation at household level for improved farm products $\left(\mathrm{Q}_{i}\right)$ for various crops $(i)$.

The unit measure of welfare benefits here are expected income streams from agricultural output in currency form per unit time realised by selling $\left(\mathrm{Q}_{i}\right)$ (farm output product(s)) associated with harvested groundwater. Thus, welfare effect can be determined using Hicksian equation functions which can be used to estimate net input factor value of water-dependent farm produce by subtracting associated farm inputs as;

$$
W B_{c}=\sum_{i} Y_{i}\left(Q_{i}\right)\left[P_{i}-C_{i}\left(Q_{i}\right)\right]
$$

Where; $W B_{c}$ are the economic or welfare benefits that are associated with irrigated farm produces; $Y_{\bar{i}}$ is the farm yields of crop (i); $P_{\bar{i}}$ is the selling price crop (i) and $C_{i}$ is the farm input cost which includes costs incurred in harvesting underground water and other associated cost of producing crops $(i)$. 
Expressed yield function in equation 4, indicates that agricultural output are directly tied to adaptive strategy of coping climatic change through underground water harvesting. Various studies (Letey et al., 1985 and Ringler and Cai, 2006) have estimated economic benefits using production function approach. Therefore, agricultural output which is reflective of welfare effect associated with harvested groundwater can be revealed in this study by using relative market price changes of the marketed commodity during wet and dry periods. These prices changes of crop output based on variance of seasons can be determined using Laspeyres Price Index function;

$$
\text { Laspeyres Index }=\frac{\mathrm{p}_{i}^{\prime} \cdot \mathrm{Q}_{\bar{i}}}{\mathrm{P}_{\bar{i}} \cdot \mathrm{Q}_{\bar{i}}},
$$

Where; $P_{i}$ represent price of crops grown during wet season and $P_{i}^{\prime}$ is the price of crops during dry season, while $Q_{i}$ is the crop output earnest from household crop land during wet season or under irrigation from harvested underground water during dry period.

The problem associated with Laspeyres Index function is the substitution bias because it doesn't account for the fact that when prices change, consumer tend to substitute to other cheaper crop products in the market. However, in this study prices sought were from essential marketed vegetable that couldn't affect its index because crops identified are consumed by most households with minimal options of substitutes.

In a price-demand function (equation 5), welfare benefits could further be expressed by integrating income stream over the incremental change of income i.e. $P_{i}\left(Q_{i}\right) \rightarrow P_{i}^{\prime} \quad\left(Q_{i}\right)$ which is a quasi-concave if represented in an indifference curve, while price change is the measure of the sensitivity of marketed products. According to Young, (2005) partial derivative which represents the slope in price-demand function, influences household decision making. Derivative function can be expressed as;

$$
\frac{\partial W B}{\partial p q}=\int_{Q 0}^{Q i} \beta_{0}+\beta_{1} Q_{i}\left(P_{i}+P_{i}^{\prime}\right)+\varepsilon \cdot d p Q
$$

Since welfare benefits (WB) is a function of income, regression model in respect to income in equation (6), that's $\sum \mathrm{Q}_{i}\left(\mathrm{P}_{i}+\mathrm{P}_{\mathrm{i}}^{\prime}\right)$ can be restated as $\Delta y=y_{0}+\mathrm{y}_{i}$ as predictor $\left(\frac{\partial W B}{\partial y}\right)$ which describe income effect to producers and inflation effect to consumers. Again, integral equation (6) can be restated as

$$
\frac{\partial W B}{\partial y}=\int_{Q 0}^{Q i} \beta_{0}+\beta_{1} y_{i}+\beta_{n} y_{n}+\varepsilon . d y
$$

Where $; \frac{\partial W B}{\partial y}=\beta_{1 i}$ when partial derivative in respect to income $\left(y_{i}\right)$ of the respective crop, describes income change of the identified crop; $\beta_{0}$ is the intercept of the OLS model; $y_{n}$ are other crops in the model; while $\varepsilon$ is the error term.

Compensating variation in equation (6) is the slope of income curve expressed as the difference between two income functions of status quo and improved income stream from micro 
Vol. 5, No. 06; 2020

ISSN: $2456-8643$

irrigation of household. The conditional effect from partial derivative of the relationship in equation (7) is:

$$
\frac{\partial W B}{\partial y} \geq 0
$$

Therefore, equation (8) represents economic definition of welfare effect from improved income resulting from water resource maximisation where benefits streams are non-declining. Thus, the main objective of this study was to examine maximization groundwater by harvesting during wet seasons when water volumes are high from unlined wells at household level in Keiyo highlands, with a view of estimating welfare effect to household if utilised through micro irrigation during dry periods. This is in view of the fact that Kenya is a water scarce country and there is therefore need to explore maximization strategies of groundwater especially during high precipitate since percolates from high rainfall has remained underutilized countrywide and in particularly the study area. Kenya's vision 2030 recognises availability and access to water as a driver that will make the realisation of blue prints which includes water and sanitation component which aims at increasing access to safe water and sanitation in both rural and urban areas beyond the present levels; to promote agricultural productivity the area under irrigation and drainage and to raise the standards of the country's overall water resource management, storage and harvesting capability. It could solve the puzzle that surround inaccessibility of water as impediment in achieving the ambitious government's big four agenda particularly the food security component.

\section{MATERIALS AND METHODS}

\section{Description of the study area}

This survey was carried out in the month of June to September in the year 2013 in the highlands of Keiyo North Sub-County in Elgeyo Marakwet County, Kenya. The study area lies between latitudes $0^{\circ} 30^{\prime} \mathrm{N}$ and $0^{\circ} 53^{\prime} \mathrm{N}$ and longitudes $35^{\circ} 20^{\prime} \mathrm{E}$ and $35^{\circ} 35^{\prime} \mathrm{E}$ (Fig. 1). The highland part in Figure 1 was selected as a study area due to its geology because it allows digging of wells by household to access groundwater for consumption. Open unlined wells are the common type of wells found in the study area.

The altitude is between $1600 \mathrm{~m}$ above sea level on the northern part and $2400 \mathrm{~m}$ above sea level on the southern part. The mean annual rainfall is $945 \mathrm{~mm}$ with a pattern showing bimodal type of rainfall with the long rains between March and June, and short rains from September to November (Kenya..., 2013). However, this rainfall patterns have remain erratic and unpredictable which is linked with climate change phenomena.

The rainfall experienced during the study period was near normal with tendency towards above normal (Kenya..., 2013). The temperature varies between $14^{\circ} \mathrm{C}$ and $24^{\circ} \mathrm{C}$ with lower altitude experiencing a higher temperature. The climate combined with type of soil tends to favour wide range of agriculture and livestock activities which account for about $90 \%$ of the economic activities. The most preferred animals reared in the study area are chicken, cattle and sheep which are often reared in paddocks, while the popular crops grown in large scale are maize and beans, while vegetables such as kales and cabbages are grown in medium and small scale. Most household grow variety of vegetables in kitchen garden with minimal irrigation. 


\section{Sampling procedure, data collection and analysis}

Sampling in this study employed multi-stage approach in selecting sample units while systematic sampling was used in carrying out interviews at household level. To determine the sample size, post-census enumeration maps and list of household at purposively selected location down to the sub-location was used.

Systematic sampling was then applied to select the sample households for interview from each cluster in the sub-location where every fifth household was selected. A starting house from a reference point such as junction of the road was randomly identified. The Interview started with the immediate household at reference point as first responded and subsequent respondents followed the right hand rule method. The sample size required for sampling was achieved by using the following formula (Kothari, 2004):

$$
\mathrm{n}=\frac{\mathrm{NC}}{\mathrm{C}^{\mathrm{s}}+(\mathrm{N}-1) \mathrm{e}^{\mathrm{x}}}
$$

Where; $n$ - size of sample, $N$ - size of population and $C$ - coefficient of variation at (30\%) confidence limit, while $e$ is the standard error at $2 \%$ level.

The target population included the entire homestead with unlined wells at the highland part of Keiyo North sub county, Elgeyo Marakwet County. To cater for spoilt and incomplete questionnaires, extra 10 questionnaires were added. The sample size determined from sample size formula was 223 households which were calculated as shown below.

$$
\begin{aligned}
& \mathrm{n}=\frac{3,800(0.3)^{\mathrm{x}}}{(0.3)^{\mathrm{x}}+(3800-1) 0.02^{\mathrm{x}}}=213 \\
& \mathrm{n}=213+10 \\
& \mathrm{n}=223
\end{aligned}
$$




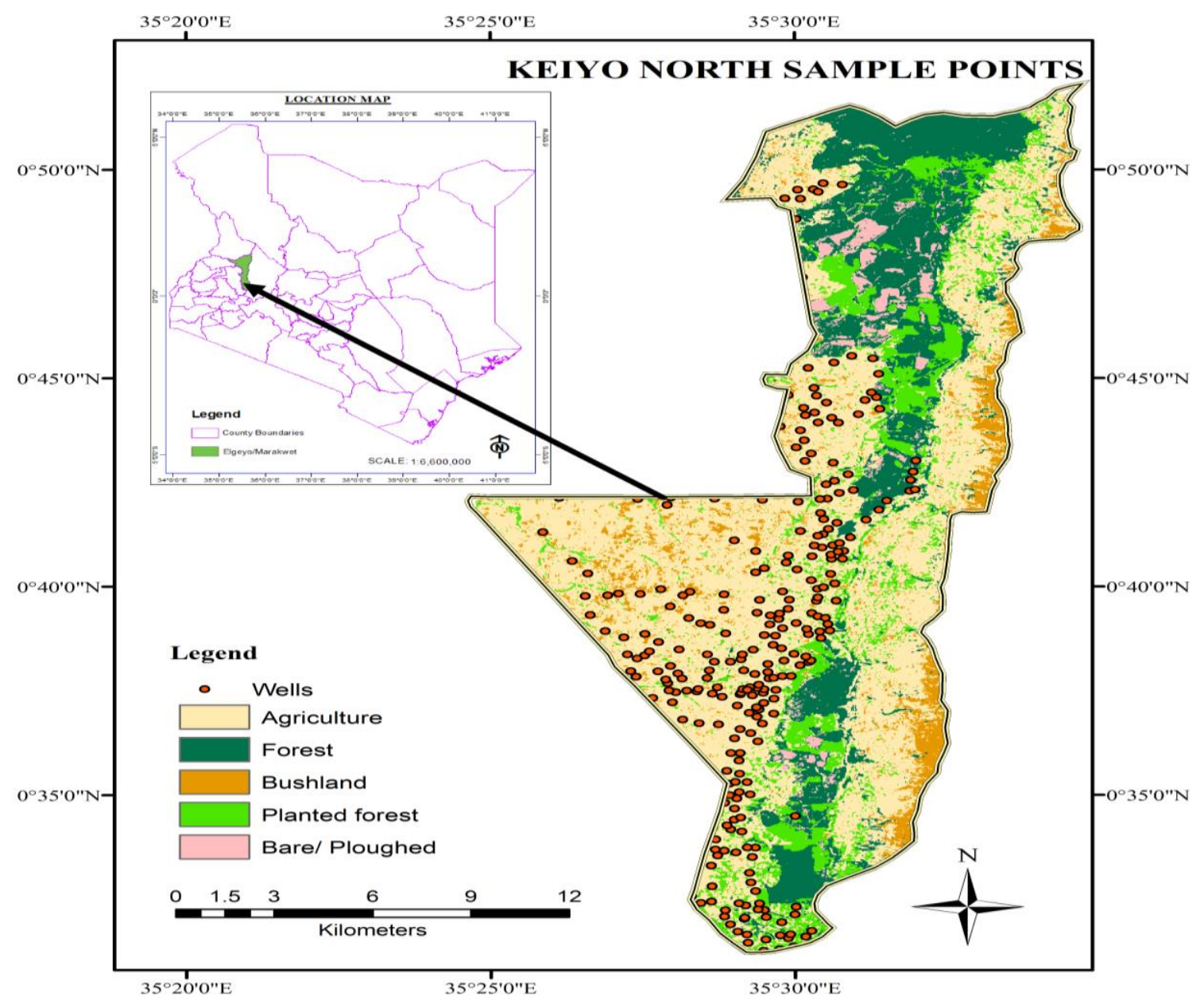

Figure 1: A map of the study area

Primary data sought was the characteristics of the unlined well owned by household. Well characteristics include diameter, the depth of the well and fluctuating level of water (during dry and wet season). These well dimensions was relevant in determining volume of water the well can hold during dry and wet period; which could inform the volume of water that could potentially be harvested from groundwater and stored for micro irrigation. Since survey was done during rainy season, it was easier to determine the highest level, while the lowest water level which is experienced during dry season was determined by taking measurement to a level the respondents often finds during dry period. Both water level point experienced during dry and rainy season in most wells sampled was visible which made it easier to take depth measurements.

All wells surveyed were unlined and circular in shape. Measurement of well diameter was taken using tape measure in-situ to aid in calculating volume of water in the well using the volumetric formula:

$$
V=\pi r^{2} h
$$


Where; $h$ was the water depth level points in the well in both dry and rainy period, while $r$ represent the radius of the well which was obtained by dividing the diameter by two.

Other information sought during data collection include socio economic characteristic of households such as possible irrigated land size, potential crops that can be put under irrigation by households, water reservoir and potential investment of water tanks.

Water recharge rate into the well was not measured in this study. However, this study relied on the research findings of Kiptum et al., (2017) who researched on groundwater recharge flow using groundwater vistas at Keiyo highlands area which is part of the study area. Groundwater vistas study used deterministic models which provides quantitative framework that reveals hydrological dynamics of underground water in wells. Since recharge of underground water is from rainfall in the study area, the recharge flow rate was computed from empirical equation suggested by Krishna Rao for areas with annual rainfall that range between $600 \mathrm{~mm}$ and $1000 \mathrm{~mm}$ (Kumar, 2015). The empirical equation used was

$$
\text { Recharge }=0.25(\mathrm{P}-400)
$$

Where $\mathrm{P}$ is the annual rainfall in millimeters

Therefore, the relied findings of mean recharge flow of groundwater into wells was 0.45 $\mathrm{m}^{3} /$ day during rainy season; porosity was at $50 \%$ and hydraulic conductivity varied from $0.05 \mathrm{~m}^{3} /$ day to $0.09 \mathrm{~m}^{3} /$ day (Kiptum et al., 2017). The information collected from respondents was used to analyse household consumptive demands of groundwater. Calculated volumetric value of groundwater in household's wells using volumetric Formula in equation 9 was used as dependent variable to regress socio economic characteristic of households. Therefore, the linear regression model used could be specified as;

Volumetric value of water in well $=\mathrm{f}$ (household population, number of animals reared, water

storage facility and other source of water)

While in equation form, it can be expressed as:

$\mathrm{Y}=\beta_{0}+\beta_{i} \mathrm{X}_{i}+\ldots \beta_{n} \mathrm{X}_{\mathrm{n}}+\varepsilon_{i}$

Where: $Y$ represents volume of the water in the well at any level; $\mathrm{X}_{i}$ are selected socio economic parameters such as household population, land size, water storage facility and other source of water; $\beta_{i}$ represent coefficient of selected parameter estimators in the regression model and $\varepsilon$ is the random factor of the model.

From selected household characteristics in the regression model (equation 11), t-tests statistics was done to determine significant influence associated with consumptive demands of underground water volume in wells by household.

\section{RESULTS AND DISCUSSION}

\section{Socio economic characteristics on water demands}

Table 1 shows determinants that influence household's water utility demands in this study. 
Vol. 5, No. 06; 2020

ISSN: $2456-8643$

Table 1: Household characteristics

\begin{tabular}{|c|c|c|c|}
\hline Variables & Value & Variables & Value \\
\hline Household size & 7.75 & Education level & \\
\hline Gender & & No Education & $7.7 \%$ \\
\hline Males & $37 \%$ & Primary level & $39.4 \%$ \\
\hline Females & $63 \%$ & Secondary level & $46.0 \%$ \\
\hline Respondents Age & & Tertiary & $6.5 \%$ \\
\hline $18-30$ & $14.6 \%$ & University & $0.3 \%$ \\
\hline $31-40$ & $39.8 \%$ & Sources of water & \\
\hline $41-50$ & $32.5 \%$ & River & $0.6 \%$ \\
\hline Above 51 & $13.0 \%$ & Well & $86.3 \%$ \\
\hline Occupation & & Rainwater & $0.9 \%$ \\
\hline Farmer & $87.9 \%$ & Piped/tap water & $0.6 \%$ \\
\hline Civil servant & $8.7 \%$ & River and well & $0.3 \%$ \\
\hline Teacher & $3.7 \%$ & Piped water/ well & $11.2 \%$ \\
\hline Others & $3.4 \%$ & Number of wells & 318 \\
\hline
\end{tabular}

Statistical tests in table 1 of household characteristics on water demand were done using percentages of the respondents. The variables used to describe household characteristic include gender, age, occupation, levels of education and water sources for household uses. From the findings, respondents interviewed revealed female where majority at about $63 \%$ while male where nearly $37 \%$. This finding could be supported by the norm in African set up that females involve themselves much on house chores and thus often found at home while males who are regarded as household providers are often out tending farming activities or external duties away from home. The average number of persons per household was 7.75 indicating high consumptive demand for water and farm output. However, such large size of household could also provide labour for food production in their farms.

Further, the result showed that about $72 \%$ of respondents are in the youthful and middle age that ranges between 31 years to 50 years. This describes the presence of high proportion of productive age of the population in the study area. Significance of productive age structure in the study area could provide enough labour in farming activities which is their core economic activity. Possible concern that can be abetted by extensive farming is environmental degradation if conservation measures by farmers are disregarded. Studies of (Rideout et al., 2013; Kerr et al., 2014 and Keenam et al., 2015) found resource degradation to be associated with anthropocentric activities.

Water is scarce resources that are dependent by all household for various uses. The most popular sources of water for household use in the study area include water from rivers, wells, rainwater, piped and/or tap water. In the study area, most sampled household either own or share wells with neighbourhood who are related as family. Among the preferred sources of water for household use as shown by the findings is well at about $86 \%$. The most cited reasons that make 
household to rely on ground water where its accessibility, reliability and multi-facet use in domestic including micro irrigation at backyard gardens.

\section{Characteristics of the Household's Wells}

In-situ measurements of the depth, diameter and water drawn per day was done to reveal household's well characteristics.

Table 2: Water volume of wells from in-situ measurement

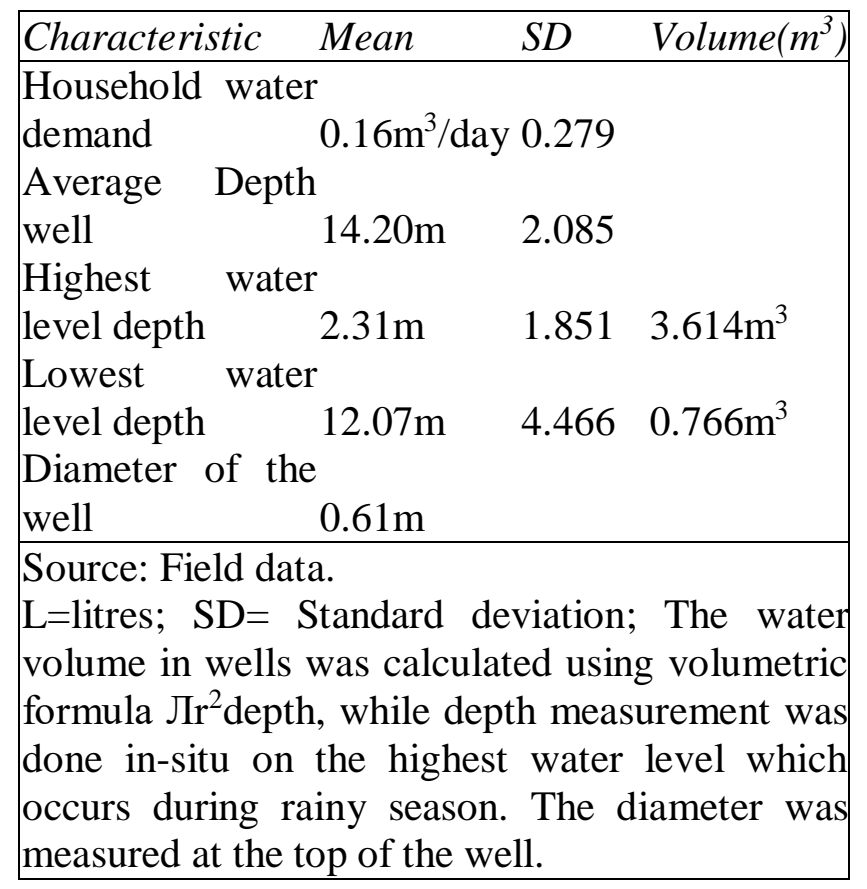

Results on wells dimensions showed that most wells had an average of $0.61 \mathrm{~m}$ in diameter, while the average depth of the maximum water level measured from the bottom of the well which was at $12.38 \mathrm{~m}$ or $2.31 \mathrm{~m}$ from the ground level often occur during rainy season. Measurement of the lowest water level which occurs during dry seasons was at $12.07 \mathrm{~m}$ from the ground level or $2.62 \mathrm{~m}$ from the bottom of the well. Using volumetric formulae in equation 9 in calculating average water volume that each well can hold at maximum was 3.614 cubic metres; while at minimum was 0.766 cubic metres.

Respondent reported months of January to March as dry period where water from wells are inaccessible due to lowest water levels, while the highest water volume is experienced during heavy rains in the months of May and September. Since water demand especially for crop irrigation are often experienced during dry seasons, then possible period of enhancing maximum water harvesting by household is in the months with high precipitation because of high recharge rate and presence of maximum water levels in household wells. Therefore, groundwater can be harvested and stored in water reservoir from the months of May to September and used for 
Vol. 5, No. 06; 2020

ISSN: $2456-8643$

irrigation during dry months from November to March of the subsequent year for sustainable supply of food crops can be achieved.

\section{Determinants of Household Water Demands}

To determine influence of household water demands, an inferential test on means of covariates was done using statistical tests.

Table 3: Determinants that influence groundwater demands

\begin{tabular}{|c|c|c|c|}
\hline Characteristics & Mean & $S D$ & Results \\
\hline Household size & 8 & 2.79 & $1.92 *$ \\
\hline No of cattle reared & 10 & 4.31 & $2.07 *$ \\
\hline Size of Kitchen & 0.22 & 0.17 & $3.75 *$ \\
\hline $\begin{array}{l}\text { Garden } \\
\text { Water storage } \\
\text { facility }\end{array}$ & $\begin{array}{c}\text { acres } \\
0.235 \mathrm{~m}^{3}\end{array}$ & 0.07 & $-0.61 \mathrm{NS}$ \\
\hline Stochastic variable & & & $1.67 *$ \\
\hline
\end{tabular}

The findings showed household population, number of cattle household rear and stated size of backyard garden a household own to significant influence water demand for consumption in wells during the dry season at $(\mathrm{t}=1.92, \mathrm{p}<0.1),(\mathrm{t}=1.2 .7, \mathrm{p}<0.1)$ and $(\mathrm{t}=3.75, \mathrm{p}<0.1)$ respectively.

This influence could manifest from high water use by household for watering kitchen gardens (micro irrigation), high demand for domestic use or and for watering reared domestic animals. Although water storage facility seemed to play critical role in water harvesting, surprisingly, it revealed negative influence $(\mathrm{t}=-0.61, \mathrm{p}<0.1)$ on water demand; that is household with less water storage capacity have wells which hold high volume of water. This could reflect satiation effect where households with generally high volume of water in all seasons in their wells for domestic use become reluctant in investing on storage water facility. However, there was a stochastic variable of $(\mathrm{t}=1.67, \mathrm{p}<0.1)$ in OLS model which showed significant influence. Stochastic variables represent some omitted parameter estimators which were beyond the scope of this study. Thus, significant influence of error term in the OLS model form the basis for a further study on other unexplained variables associated with household water demand.

\section{Volumetric Water for Harvesting from Household's Wells}

Table 3 shows computed amount of groundwater in household wells that can be harvested for micro irrigation during dry period. To determine water volume of groundwater per well $\left(3.614 \mathrm{~m}^{3}\right)$ in table 3, volumetric formula described in equation 9 was used. The month of May and September was used as the maximum period that experience high precipitation of $\leq 945 \mathrm{~mm}$ 
and recharge rate of $\leq 0.45 \mathrm{~m}^{3}$ per day. These two months of high precipitation and recharge rate as described in the study of Kiptum et al. (2017), is an ideal period that allows high water level in the well. Therefore, the periods where household wells experienced high water level could necessitate harvesting of groundwater and stored in an artificial water reservoir.

Table 4: Potential groundwater to be harvested

\begin{tabular}{|c|c|c|}
\hline Description & Calculation & Results \\
\hline $\begin{array}{l}\text { Volume of water } \\
\text { per well }\end{array}$ & $\begin{array}{c}\left(3.142 \times 0.3^{2} \times 12.07\right. \\
)\end{array}$ & $3.614 \mathrm{~m}^{3}$ \\
\hline \multirow[t]{2}{*}{ Recharge duration } & $3.614 \mathrm{~m}^{3}$ & 8 days \\
\hline & $\overline{0.45 \mathrm{~m}^{3} / \text { day }}$ & \\
\hline $\begin{array}{l}\text { Rate of harvesting } \\
\text { water during May }\end{array}$ & 30 days $\times 2$ & 7 times \\
\hline and September & $\overline{8 \text { days }}$ & \\
\hline $\begin{array}{l}\text { Assuming all } \\
\text { water in } \\
\text { household well is } \\
\text { harvested; then } \\
\text { maximum water } \\
\text { that can possibly } \\
\text { be harvested in } \\
\text { wet month }\end{array}$ & $\left(3.614 \mathrm{~m}^{3} \times 7\right)$ & $25.298 \mathrm{~m}^{3}$ \\
\hline
\end{tabular}

Based on the prevailing condition of rainfall at $\leq 945 \mathrm{~mm}$ per annum and recharge rate of $\leq 0.45 \mathrm{~m}^{3}$ per day, maximum mean volume of water that can be harvested and stored is 25.298 cubic metres at an interval 8 days in the two months were heavy rainfall are experienced in the study area. In these two months (May and September) in which high precipitate of $\leq 945 \mathrm{~mm}$ and maximum recharge rate of $\leq 0.45 \mathrm{~m}^{3}$ per day is experienced in the study area, groundwater harvesting can be done 7 times. However, other months with moderate rainfall, could allow groundwater harvesting, thought at minimal. This could reveal that 25.298 cubic metres is the minimal volume of water that could be harvested.

\section{Predicted Welfare Effect from Harvested Groundwater}

Table 5 shows the summary of the market prices during wet and dry period of identified crops grown in the household kitchen garden.

Table 5: Estimated income during wet and dry season

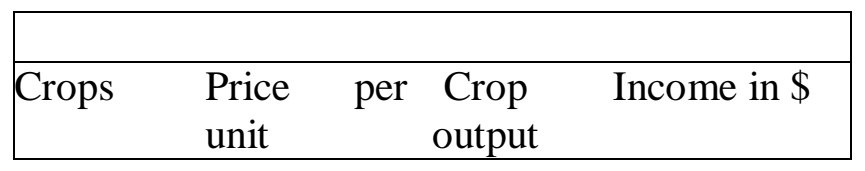




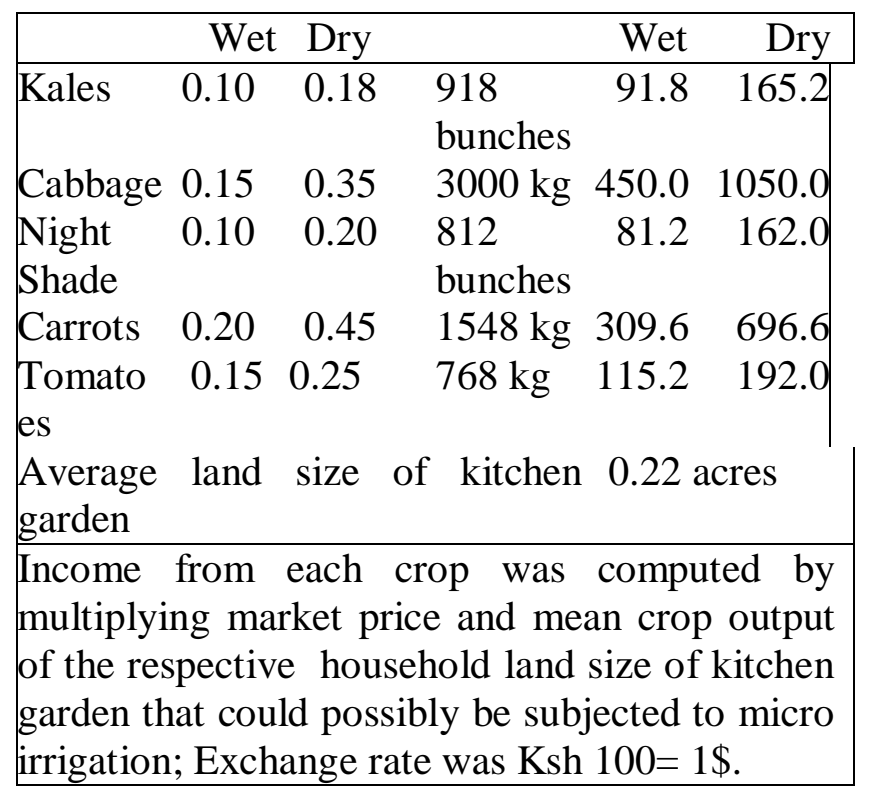

Crops grown by household during dry period using harvested water from wells for micro irrigation is assumed to yield similar production. Variance on prices arises when disequilibrium from market forces commodity in terms of supply and demand from differ during wet and dry seasons as depicted in the results; revealing possible improved income during dry season to producer if micro irrigation.

Table 6: Implied income effect by crop type

\begin{tabular}{|lcc|}
\hline & & \\
\hline Crops & $\frac{\partial W B}{\partial y}$ & $\frac{\mathrm{P}_{\mathrm{i}}^{\prime} \cdot \mathrm{Q}_{\bar{i}}}{\mathrm{P}_{i} \cdot \mathrm{Q}_{i}}$ \\
\hline Kales & 0.800 & 1.80 \\
Cabbage & 1.333 & 2.33 \\
Night & 0.995 & 2.00 \\
Shade & & \\
(Managu) & & \\
Carrots & 1.250 & 2.25 \\
Tomatoes & 0.668 & 1.67 \\
\hline All crops & 1.009 & 2.01 \\
\hline
\end{tabular}

Partial derivatives of predictor crops which are the predicted output in terms of income in equation 7 describe income effect. The results from derivatives from regression model on specific crops grown at the backyard garden revealed to positively influence household income at the range from 0.668 to 1.333 percentages point, while the implied coefficient value which is the aggregate income effect from all crops studied is 1.009 percentage points. Income effect 
during dry seasons, if micro irrigation is practiced at backyard garden on identified crops of cabbage, carrots, Black nightshade (Managu), kales and tomatoes could result into 1.333, 1.25, 0.995, 0.8 and 0.668 percentage point increase, respectively. Percentage point increase from farm crops identified predicted the rate at which welfare improvement on income if micro irrigation is practiced at household backyard gardens, provided groundwater is harvested during wet seasons. These findings reflect a "well-behaved" characteristic that conform to economic theory of resource maximization described in equation 8 (Ringler and Cai, 2006). Other studies (Letey et al., 1985; Stavins et al., 2002; and Kiptum et al., 2017) revealed similar findings where improvement of income stream arises when scarce resources are maximized.

Price index from Laspeyres Index function reveals marginal improvement effect on income from market basket of goods (Kales, Cabbages, Night shade Carrots and tomatoes). Improved income effect on percentage point from popular crops that are often put under micro irrigation by household such as Kales, Cabbages, Night Shade Carrots and tomatoes were 1.8, 2.33, 2.0, 2.25 and 1.67, respectively, while aggregate welfare effect from all crops identified were 2.01 percentage points. Expected increase from farm output prices on the identified crops during dry season could reveal compensating variation value to farmers who probably could be willing to invest into groundwater harvesting for micro irrigation. That is, a household that could possibly embrace groundwater harvesting strategy for micro irrigation on identified crop production such as Kales, Cabbages, Night shade Carrots and tomatoes could make them improve by a margin of twofold percentage point on income.

\section{CONCLUSION}

The findings of this study describe the consumptive demand of groundwater at household level to be influenced by socio economic characteristic such as household size, number of cattle owned by household and the land size of backyard garden. However, influence of the above mentioned socio economic characteristics seemed to be limited and cannot solely be relied upon as depicted by random factor in the regression model, which revealed other unobserved variables could influence household water demands. In view of that, therefore, it is recommended that other socio economic factors that were beyond the scope of this study be investigated more.

Again, the potential of harvesting groundwater during wet season for micro irrigation at backyard garden of a household during water scarce periods, revealed to significantly improve the welfare of the household and sustainable supply of food and essential nutrition to the population. Therefore, influence of harvested groundwater at household wells for micro irrigation could give plausible direction in policy formulations that are geared in alleviating poverty and cushion supply of food to the population from extreme environmental events. Since this study didn't find out the costs implications and modalities of drawing groundwater into the storage reservoir which is critical in achieving its potential, it creates knowledge gap which needs further study.

\section{Acknowledgements}

The authors thank household heads who participated in sharing valuable information that necessitated this study to be successful. 
Vol. 5, No. 06; 2020

ISSN: $2456-8643$

\section{REFERENCES}

Booker,J. Amd Young, R.A. 1994. Modelling intrastate and interstate Markets for Colorado River Water Resources. Journal of Environmental Economics and Management. 26(1):6687. http://www.sciencedirect.com/science/aerticle/pii/s0095-0696(84)71005-9.

Brassington, R., 2007. Field Hydrology (3rd ed.). John Wiley \& Sons LTD, West Sussex.https://doi.org/10.1002/9780470057032

Cao, G.; Zheng, C.; Scanlon, B. R.; Liu, J.; Li, W. 2013. Use of Flow Modelling to Assess Sustainability of Groundwater Resources in the North China Plain. Water Resource Research, 49, 159-175. https://doi.org/10.1029/2012WR011899

Chen, H.; Wang, S.; Gao, Z.; Hu, Y., 2010. Artificial Neural Network Approach for Quantifying Climate Change and Human Activities Impacts on Shallow Groundwater Level: A case study of Wuqiao in North China Plain. In: 18th International Conference on Geoinformatics Proceedings, 18th -20th June 2010, IEEE: New York, NY, USA. https://doi.org/10.1109/GEOINFORMATICS.2010.5567678

Fei, Y.; Miao, J.; Zhang, Z.; Chen, Z.; Song, H.; Yang, M., 2009. Analysis on Evolution of Groundwater Depression Cones and Its Leading Factors in North China Plain. Resource Science, 31, 394-399.

Kelemen E., Garcia-Llorente M., Pataki G., Martin-Lopez B. and E. Gomez-Baggethun .2016. Non-Monetary Technique for the Valuation of Ecosystem Services. In: Potschin M and K. Jax (eds): OpenNess Ecosystem Services Reference Book. EC FP7 Grant Agreement no. 308428. www.openness-project.eu/library/reference-book

Kemper, K. E., 2004. Groundwater: From development to management. Hydrogeology, 12(1), 35. https://doi.org/10.1007/s10040-003-0305-1

Kenya Meteorological Department, 2013. The Outlook for the March-April-May (MAM) 2013 "long-Rains" Season in Kenya and Review of the Performance of the October-December 2012 "Short Rains" Seasons as Well as The Weather during January-February 2013. Report from Government of Kenya [online], [cited 7 July 2018]. Available at: https://reliefweb.int/sites/reliefweb.int/files/resources/The\%20outlook\%20for\%20the\%20M arch-April-May\%20\%28MAM\%29\%202013\%20\%E2\%80\%9CLong-

Rains\%E2\%80\%9D\%20season\%20in\%20Kenya.pdf

Kiptum A. R. and Chebet, C. S. (2017). Determinants of Groundwater Retention in Wells: A Case of Keiyo North District, Elgeyo Marakwet County, Kenya. Journal of Water Security,

3. Article Number: jws2017007 Doi: https://doi.org/10.15544/jws.2017.007

Kiptum A., Meli, J \& Saina, C. (2017). Benefits of Kitchen Gardening. A case of Nandi Tea Estate, Nandi County, Kenya. Africa Environmental Review Journal, 2(2):55-64. Available at http://www.aerjournal.info

Kiptum, A., Kipkoech, A., Wario R. A., Odipo O., Byamukama Biryahwaho, B \& A. Agasha. (2012). Impacts of Community Activities on Environmental Resources: The Potential for Developing Payment Schemes for Environmental Services. In Anderson et al (2012). Towards Implementation of Payment for Environmental Services (PES): A collection of findings linked to the ASARECA funded research activities. Pg 290-300. VDM Verlag Dr. Müller, Germany. https://www.researchgate.net>publication 
Vol. 5, No. 06; 2020

ISSN: $2456-8643$

Kiptum, C.K., P. Mbaka \& J.K.Mwangi (2017). Application of Groundwater Vistas in Modelling Groundwater Flow in Keiyo Highlands. African Environmnetal Review Journal. Vol 2(2): 33-45. http://www.aerjournal.info

Konikow, L.; Kendy, E., 2005. Groundwater Depletion: A Global Problem. Hydrogeology, 13(1), 317-320. https://doi.org/10.1007/s10040-004-0411-8

Kothari, C. R. 2004. Research Methodology, Methods and Techniques (2nd ed.). New Age International (p) Ltd. Publishers, New Delhi [online], [cited 16 July 2018], Available at: https://www.modares.ac.ir/uploads/Agr.Oth.Lib.17.pdf

Kumar, C. P. (2015). Groundwater Assessment and Modelling. Kindle Edition. 1259.

Letey, J., Dinar, A. and Knapp, K.C. 1985. A Crop Water Production Function Model for Saline Irrigation Waters. Soil Science Society of America Journal, 49(4). Doi:102136/sssaj1985.03615995004900040043x.

Mogaji, K. A.; Aboyeji, O. S.; G. O. Omosuyi, 2011. Mapping of Lineaments for Groundwater Targeting in the Basement Complex Region of Ondo State, Nigeria, Using Remote Sensing and Geographic Information System (GIS) Techniques. International Journal of Water Resources and Environmental Engineering, 3(7), 150-160 [online], [cited 21 July 2018]. Available at:http://www.academicjournals.org/journal/IJWREE/article-full-textpdf/57F993F54739

Nepal, M., Bohara, A.K., and Gawande, K. 2011. More Inequality, More Killings: The Maoist Insurgency in Nepal. American Journal of Political Science, 55(4):886-906. Doi 10.111/j.1540-5907.2011.00529.x

Pastakia, O. 2011. Livelihood Augmentation in Rainfed Areas. Gujarat, India: Development Support Centre (DSC)

Rideout A., N. Joshi and K. Viergever (2013) Making Predictions of Mangrove Deforestation: A Comparison of Two Methods in Kenya. Glob Chang Biol 19:3493-501 SCBD (2009) Biodiversity for development and poverty alleviation. Secretariat of the Convention on Biological Diversity, Montreal

Ringler, C. and Cai, X. 2006. Valuing Fisheries and Wetland Using Integrated EconomicHydrologic Modelling - Mekong River Basin. Journal of Water Resources Planning and Management, 132(6): 480-487. Doi:10.1061/(ASCE) 0733-9496(2006) 132:6(480)

Stavins, R., Wagner, A., Wagner, F., (2002). Interpreting Sustainability in Economic Terms: Dynamic Efficiency Plus Intergenerational Equity. Resource for the Future Discussion Paper 02-29, Washington, DC.

Wada, Y.; Van Beek, L. P. H.; Van Kempen, C. M.; Reckman, J. W. T. M.; Vasak, S.; Bierkens, M. F. P. 2010. Global Depletion of Groundwater Resources. Geophysical Research Letters, 37. https://doi.org/10.1029/2010GL044571

World Bank. 2011. Exporting Environmental Services; A Developing Country Perspective. New York: World Bank.

Young, J. 2005. Research, Policy and Practice: Why Developing Countries are Different. Journal of international development, 17(6). https://doi.org/10.1002/jid.1235 